\title{
How Did Popular Music Come to Mean Música Popular?
}

\author{
Laura Jordán González and Douglas Kristopher Smith \\ Universté Laval, Québec / Concordia University, Montréal, Canada \\ laura-francisca.jordan-gonzalez@ulaval.ca / dsmit@alcor.concordia.ca
}

\begin{abstract}
Produire la définition d'une catégorie musicale revient en effet à prendre un risque : celui de se voir contesté, démenti, désavoué ou révoqué. ... De la recherche à nos conversations ordinaires, c'est mettre en cause son appartenance à une communauté discursive - Nicolas Jaujou (2002)
\end{abstract}

\begin{abstract}
The field of popular music studies has grown to include participation from many different parts of the world, comprised of cultural-linguistic spaces that view popular music in a dissimilar and sometimes contradictory light. That said, there have been situations where two or more very different definitions of popular music exist side by side, further complicating the coherence of the field. Focusing on Spanish-speaking Latin America, we set out to examine what popular music and música popular have meant in some of their respective sociolinguistic spaces, and argue that disparities of legitimacy between institutions that are engaged in the study have contributed to a terminological confusion that must be further engaged with if it is to be overcome.
\end{abstract}

Keywords: Popular music, música popular, translation, terminology, disparity

\section{Introduction}

Popular Music Studies, as an interdisciplinary field tasked with studying musics traditionally left out by academia (Moore, 2003, p. 1), has had to come to terms with the various interpretations of the nature of the object of studies at hand. In spite of the continuous and lively debate around what popular music, or for that matter, Popular Music Studies, is or is not, the fact is that there are dominant observable tendencies that indeed dictate what it is, at least in practice rather than in theory.

So as the title states, in Spanish-speaking Latin America popular music has at times come to mean música popular (or vice versa depending on your vantage point, of course), in some cases side by side and in others blurring the lines between how those terms ${ }^{1}$ have been understood in their own respective cultural linguistic contexts prior to the structuring of the study of popular music as a field, brought about in part by the founding of the International Association for the Study of Popular Music (IASPM). It is, of course, inevitable that terms change, transform and take on new meanings over time, in both a positive and negative sense. However, in this article we propose to look at how and why this has taken place over such a short period of time and suggest other ways of engaging with these various understandings of popular music that coexist in this field of study, but not always with equal consideration. 
As we will examine in more detail, a lot of this terminological confusion has to do with the word popular and its various meanings in the many linguistic spheres where popular music is formally studied. Therefore, we hope this article to be an expansion of recent studies, such as those of Franco Fabbri (2010) and Sydney Hutchinson (2011) respectively, that others can later take up and expand, applying it to their own sociolinguistic contexts, or look outside of academic language, for example, in the print media, or the terms employed by the musicians themselves (as did Hutchinson), which we unfortunately do not have the time to talk about in adequate detail and would feel it unwise just mentioning it in passing.

In the first part of this article, we will give a detailed descriptive analysis of the ways in which popular music and música popular have been understood and the various debates around those understandings. We will then segue to an analysis of the translation and transformation of these notions in a framework critical and postcolonial linguistic and cultural theory.

Suffice to say that, ironically, as we were writing our analysis of these terminological difficulties, when we got to some of the very quotations in this paper, we were very much put in a situation that can be thought of as a microcosm of the larger problem at hand. For that reason, all quotations coming from languages other than English, like those in the section on música popular, will include the original text below our English translation.

\section{How has popular music been defined?}

The entry in the Grove Music Online encyclopaedia offers a multi-faceted definition for popular music, written by Richard Middleton and summarizes a large and arduous debate carried out by scholars over the last few decades. According to Middleton, there have been several criteria used to define popular music, criteria reduced to three main groups. First, it is defined by its "popularity" in terms of its wide reception; second, said popularity is linked to means of dissemination via the mass media; and third, it is linked to a particular social class: the people (generally understood as the working class, but at times marginalized peoples in general). These three criteria show their fragility as they are packed together indiscriminately and without considering historical and local particularities of the context in which music, as well as the terms used to describe it, is produced and experienced. Finally, he offers a fourth criterion, one that defines popular music in opposition to art music, which may be the less polemic, except in certain cases where classical and art music repertoires are taken out of their usual institutional settings.

Usually, mass culture is examined in relation to media and industry. However, this criterion by itself refers to the quantity of people listening to said music, which supposedly defines its "popularity". John Blacking, in effect, rejected the definition of popular music based on mass culture, arguing that a massive reception was not an exclusive characteristic of any particular kind of music, and the same was true for the criterion of musical quality (Blacking, 1982, p. 11-14). A similar point of view appears in Walter Wiora's chapter "Popularization and Depopularization", where he described what he sees as a "democratization" of musical life by the means of mass dissemination of classical, folk and entertainment popular music (Wiora, 1966, p. 161). Therefore, the mass culture criterion is not sufficient enough to distinguish the meaning of popular music, as stated in John Storey's Inventing Popular Culture:

\footnotetext{
The influence of seeing popular culture as mass culture is very difficult to overestimate: for more than a century it was undoubtedly the dominant paradigm in cultural analysis. Indeed, it could be argued that it still forms a kind of repressed "common sense" in certain areas of British and American academic and nonacademic life. (Storey, 2009, p. 30)
} 
In terms of the media, Theodor W. Adorno had proposed in 1941 to observe musical and social elements in order to understand the history of the division between serious and popular music. Adorno's method was an analysis of the major differences as they appeared within the musical production process, and this as a part of a bigger entreprise: understanding the culture industry. However, the very definition of popular music by Adorno does not seem sufficiently clear, because he compares a multiplicity of musical styles to serious music, e.g. light music, hit tunes, dance music, jazz and folk music (Paddison, 1982, p. 208). Even if the pejorative treatment Adorno gave to popular music was not very well received by scholars in the field, the importance he attributed to the system of production, including the centrality of technology and dissemination of entertainment music, is an aspect that has given his critique lasting relevance.

Adorno's proposition confers a central role to the industry and the means of production as elements that profile what is popular music in opposition to other kinds of music. Therefore, it seems fair to consider how the music industry has been developed beyond metropolises, paying attention to particular circumstances of production and dissemination of musics, both locally and globally. Moreover, by accepting the transformative quality of history, the usage of categories should be adapted to different industries, audiences, artists and changes in scholarship. In much the same manner, Peter Manuel explains that the English term is intimately related to modernisation, in reference to popular musics of "the world" (a problematic approach denoting the world outside of developed countries):

The term 'popular music' is used here to connote genres whose styles have evolved in an inextricable relationship with their dissemination via the mass media and their marketing and sale on a mass-commodity basis. Distinctions between popular musics (defined thus) and other kinds of music, such as commercialized versions of folk musics, are not always airtight. (Manuel, Grove Music Online).

Consequently, the second criterion relative to the mass media and cultural industry posits the types of music developed under a specific economic system with commonly-used technologies of mass-dissemination as "popular music", that is, musics produced in era of late-capitalism (from approximately 1945 onwards), within the socalled industrialized world.

With respect to "popular" or "popularity" and their links to the people, the first volume of the journal Popular Music had taken on the task of defining the concept providing arguments that still resonate today. Middleton, the volume's editor, described one of the several meanings established around the adjective "popular": one related to the people, alluding to Raymond William and Peter Burke's contribution in the field of cultural studies.

In England at least, by the sixteenth century, 'popular' began to lose earlier neutral usages ('belonging to the people'), and to take on an evaluative function: the implication was that this was a term applied to 'them' (the 'common' people) by 'us' (see Williams 1976, pp. 1999), and it represented a progressive withdrawal by upper and educated classes from previous notions of a common culture (see Burke, 1978, pp. 270ff). (Middleton, 1981, p. 4)

Richard Shusterman had a similar impression arguing that the understanding of the word "popular" via "mass culture", whose use serves to avoid negative connotations attributed to the term "mass", is relatively modern. In English, the usage of the expression "popular art":

$\ldots$ is relatively modern and somewhat ambiguous; its English usage seems to date only from the nineteenth century, and the term seems also applicable to what might more aptly be called "folk art" and not only to the modern mass-media arts of the 
entertainment industry, which today is its main meaning. (Shusterman, 2003, p. 290)

On the other hand, in The Oxford Companion to Music, Peter Gammond and Kenneth Gloag recognized the intricacy of defining the term popular music. Typically used in Europe and North America since the nineteenth century to designate music from industrialized countries and modern music, the two authors claim that the term is "used widely in everyday discourse, generally to refer to types of music that are considered to be of lower value and complexity than art music, and to be readily accessible to large numbers of musically uneducated listeners rather than to an élite" (Gammond \& Gloag, accessed on Nov.13, 2010).

Yet, it is practically impossible to define popular music in a coherent and univocal manner due to the conflicts around relative applicability of the diverse meanings that surround the term (Hesmondhalgh \& Negus, 2002, p. 2). And this becomes even more daunting when one tries to find equivalents in other languages.

Flexibility, in accordance with Middleton, is necessary to adequately handle the term "popular music" as all the criteria may not apply equally and at all times. This same flexibility is also suggested by Philip Tagg in his axiomatic table that includes art music, popular music and folk music, visually demonstrating the multiple intersecting criteria frequently attributed to the three categories and the ways in which they differ and are alike (1982).

Neither the diverse coexistence of definition-criteria, nor the impossibility of unifying the meaning of popular music are in themselves problematic, quite the contrary. Rather, it seems necessary to observe the inherent ideological implications that the selection of one criterion or the other in the development of Popular Music Studies can entail. If the aspect of mass popularity no longer seems particularly relevant to specifying the object of study, the assumed role of the mass media, however, does indeed suggest a line of demarcation, as previously mentioned, in terms of the technological and economic development of invariably specific social and material realities. On the other hand, the "people" as another essential criterion, also tends to lack clarity due to the various interpretations as to what is actually meant by the "people", be it political subjectivity, social class, the result of modern nation-building imaginaries, the masses etc., which run the gamut of different - and at times opposing - ideological positions. Naoki Sakai, who we will revisit in more detail when taking up the issue of translation, rightly draws a parallel between the ideological implications of demarcation, stating that "Just as bordering is not solely about the demarcation of land, translation is not merely about language" much like defining concepts is not merely about their understanding (Sakai, 2010, p. 25).

Considering that it is not the unification of the definition of popular music for which we are advocating - but rather an awareness of what is implied by drawing these lines of demarcation - our concern is based on the similar difficulties found in different linguistic spheres that do not mirror those of English (the de facto lingua franca of academia), as well as other issues that arise from the intervention inherent in the (very necessary, yet often problematic) act of translation.

\section{And now, música popular?}

Much like in Spanish, in several other Latin-based languages, French and Italian for example, the term popular - populaire, popolare - opens up a range of new semantic possibilities.

In French, there has been an observable transformation in the dominant meanings of musique populaire over the years. For instance, in 1961 Lacourcière (1961, p. 375) established a definition similar to that of folk music, while in 1959 Diego Carpitella discussed the tension between rurality and urbanity in Italy linked the 
emergence of a musique populaire disconnected from traditional patrimony (Carpitella, 1959, p. 68). Melpo Merlier gives another example in an article about Greek popular songs, where he states that musique populaire will continue to be an expression of tradition (Merlier, 1960, p. 76), establishing a link to musique traditionnelle. Recently, de Surmont denounced contradictory meanings of the term, which was formerly used to designate traditional or "preindustrial" music and presently for music written by famous songwriters [auteur célèbre] (De Surmont, 2008, p. 84). Nevertheless, the earlier understanding of populaire seems to prevail as it is connected to the word song, rather than the word music (chanson populaire versus musique populaire).

\begin{abstract}
Popular is diachronically polysemous. It meant 'traditional', and then 'meant for the people'. 'Commercial, industrial', and successful songs are not really referentially precise because they can refer at the same time to traditional song and rock song, folksong, and progressive music (song). We must then add another adjective: to 'traditional song' and 'literary song', at the same time isolating the notion of 'more or less successful' and 'voluntarily destined to the masses'. Then we could say chanson traditionelle populaire (or commerciale), and chanson signée à texte and chanson signée à succès. (De Surmont, 2008, p. 88.)
\end{abstract}

Also, in Italian, there have been similar observations made around the issues of translation and contact with dominant English-language cultural and academic institutions, Franco Fabbri states:

We must conclude that terms used to indicate musical genres are extremely difficult to translate, and have different meanings in different languages and cultures: here a term not only connotes different things for two different people according to the diversity of their interests in the denoted object and therefore according to the diverse processes of understanding involved - but precisely denotes two different things. What is the relationship between these meanings within the same culture? And in different cultures? So, the second factor mentioned above has also returned us to the question of meaning. (Fabbri, 1982, p. 132.)

As Fabbri pointed out, not only does the term popular music have various connotations, but presents a whole range of semantic possibilities in translation. In romance languages, the word popular often has a class-based connotation, as Middleton suggests, also referring usually to music coming from an oral and/or rural tradition. Therefore, the literal translation of popular music brings us to a type of music generally considered folkloric, ethnic or traditional. However, as Fabbri stated as early as 1982, in Italy the notion of musica popolare tends to reference what in "Anglo-Saxon countries is called 'folk music'; while 'pop' was once synonymous with 'rock' and today is often used to indicate 'English rock music of the seventies'" (Fabbri, 1982, p. 132). This raises two important questions regarding the translation of popular music: [1] In terms of the proximity of the notion of popular to folkloric (i.e. traditional folk music), and [2] regarding the variability of the word popular which draws a parallel to the music style known as pop, but also to other styles that also happen to share the same social space via its presence in the mass media, its mass dissemination and its Anglo-Saxon origins, like rock, for example. Therefore, the meanings of musique populaire and musica popolare are not only multiple, but also seem to coexist in the same linguistic sphere.

In the case of Spanish, the language in question, the Argentine musicologist Carlos Vega defined música folklórica as one of the various types of música popular, positing, in opposition, the urban songs and dances coming from aristocratic circles, anthems and patriotic nationalist marches as popular, but non-traditional folk musics. Later, Vega expressed his uncertainty with the term música popular: 


\begin{abstract}
The term "popular" has multiple meanings, but in nearly all its nuances, it relates to the middle and lower social strata and even to rural groups and what are called the "folk." Insofar as it is contrasted with the educated classes, it alludes to semiliterate and illiterate groups-common, simple, uncultivated. In Spanish, moreover, "popular" is also synonymous with "plebeian" (as opposed to gentle or noble), and both "pueblo" and "plebe" are on occasion equivalent to "populacho" (populace or rabble), which is the lowest class of all. The roots of the Spanish "vulgo" (vulgus) and of "folk" appear to be the same. (Vega, 1966, p. 2.)
\end{abstract}

Consequently, Vega concluded by defining música popular as the minor creations, strongly associated to the idea of the "people", i.e. rural, lower, less distinguished classes which, by extension, included rural or "folk" classes (Vega, 1997). Curiously, few South American musicologists had the same insight as Vega at that time. On the other hand, his usage of the term tends to be quite overreaching, pejorative, and at times, unclear.

As we have seen, regarding the examples in French and Italian, multiple meanings can coexist within the same language. Similarly, what we have observed in a variety of texts published in Spanish is the use of the word "popular" to refer to categories defined by more than one meaning. For instance, Rodrigo Torres (2008) applies the term "popular" to musics and celebrations of marginalized classes and indigenous populations (third criterion), which specifically include, in the context of the nineteenth century, the genre of zambacueca or cueca; but at the same time he alludes to its mass dissemination (first criterion). Furthermore, Samuel Claro, in his book Oyendo a Chile (1979), uses the term música popular in reference to secular peninsular Spanish musics that came to the Americas starting in the sixteenth century, as well as in reference to famous songs from the twentieth, including a wide range of genres according to three main periods: [1] waltz, march, mazurka, habanera, redowas, tonada, canción and zamacueca; [2] shimmy, corrido, foxtrot, one-step, tango, Boston and ragtime; [3] rock, bolero, ballad, cueca chilenera (Claro 1979: 19). The inclusion of diverse kinds of music seems coherent considering, again, the first and third criteria. Also double meanings are observed in some articles published in the Spanish journal Trans, where música popular is used, for instance, [1] to describe música gallega, in reference both to mass culture and national/traditional culture (Costa 2004) and [2] to approach the dissemination of música popular cubana, referring to the term popular as relating both to the masses and the lower social classes (Eli Rodríguez, 2005).

The point we are trying to make here is, on one hand, to stress the coexistence of meanings of the word popular within the same text; and on the other, to reveal a recurrence of two main meanings: mass dissemination and people. Both can be also found, but not openly, in a third example from Chile, in an article by Jorge Aravena Décart (2008), who defines the range of popular solely in contrast to music considered to be serious or erudite, understanding música folklórica as a subcategory contained within música popular, in such a way that, for him, the former was the first dimension of the latter in order to obtain musicological attention.

A different position is expressed by Juan Pablo González (2001), who puts forth a definition of música popular based on the criteria of mass culture (ironically, usually referred to in English as popular or pop culture), the centrality of its diffusion via the mass media and its "modernizing" qualities, as the elements that define the field of the study and differentiate it from folk or traditional music studies.

Disagreements, at times antagonistic, around the different interpretations of música popular and the conflicts of power they entail have been part of the academic discussion among members of the Latin American branch of IASPM as well. Getting back to the previously mentioned definition of música popular, which is also the 
working definition of IASPM Latin American adopted at the 1997 conference, Juan Pablo González (2008) says:

\begin{abstract}
It should not try to take on the entire range and variety of Latin American popular musics, but rather emphasize a particular musical practice that has been overlooked by musicology and ethnomusicology until the $80 \mathrm{~s}$. It is about a musical practice that is urban (or urbanized), defined by its general popularity, dissemination in the mass media and modernity. In that sense, the idea was to differentiate ourselves from the study of community and oral-based traditional musics, while not losing focus on the intersections that come about between both fields of study. ${ }^{2}$
\end{abstract}

Nevertheless, academics such as Chalena Vásquez insist that this would amount to denying that some traditional musics are popular (see, for example, the debate that took place on the IASPM-AL email discussion list in 2006), meaning both that they are mass disseminated and of the people, even if they are not produced within the so-called cultural industry.

A really important contribution to this debate is the recently published article entitled "Típico, folklórico or popular? Musical categories, place, and identity in a transnational listening community." In this article ethnomusicologist Sydney Hutchinson examines the disparities between the uses of the terms típico, folklórico and popular often used to describe (and in many way impose themselves upon) non-erudite musics in Latin America in academic texts, and the uses espoused by lay people and the musicians themselves. She then goes on to suggest that the most logical nomenclature to use is that of "place", e.g. emic terms employed in social spaces in which the musical practice is carried out, which often differ and at times contradict those used by academics, but not without their own local contradictions and transformations which must not be oversimplified either (Hutchinson, 2011).

While we tend to agree wholeheartedly with her critique, our insistence in problematizing the uses of popular music has much more to do with the disparities within the study itself, rather than between researcher and the music and musicians in question. Our argument is that within Popular Music Studies in general, there is also an etic and emic disparity between the different institutional spaces in which these studies are carried out and that the concepts used also have their local connotations (as Fabbri duly noted) on a scholarly level as well.

\title{
How are popular musics often conceptualized in Latin America?
}

The identification of a kind of music developed within the cultural industry, where mass dissemination is fundamental and which constructs its musical languages alongside advances in technology, does not rely on the use of the term "popular". Multiple epithets have been proposed to cover, more or less, the genres and repertoires designated in English under the label "popular music". Just to name a few, we find musica extracolta (Pestalozza, quoted in Fabbri, 1982, p. 133), musica di consumo (Somigli, 2001), musique artisan-populaire (Carpitella, 1959, p. 67), chanson signée à succès (De Surmont, 2008, p. 88), etc.

In Spanish, for instance, an alternative term was proposed by Carlos Vega in 1966 called mesomúsica.

Mesomusic is the aggregate of musical creations (melodies with or without words) functionally designed for recreation, for social dancing, for the theatre, for ceremonies, public acts, classrooms, games, etc., adopted or accepted by listeners of the culturally modern nations. During recent centuries, improvements in communication have favoured the dissemination of mesomúsica to such a degree that today the only exceptions to its influence are the more or less primitive aborigines and the national groups that have not yet completed their process of 
modernization. But since mesomúsica is not an exclusively Western music but rather a "common music" of mankind, there can exist eccentric foci with dispersal over wide areas of the world. (Vega, 1966, p. 3.)

In spite of ideological problems we found in Vega's explanation, mainly expressed in his disdain for what he calls "primitive aborigines" seen as impediments for progress, the perspicacity required to identify a new field of music, distinct from what was predominantly understood by música popular, that is música folklórica and tradicional, is quite exceptional. Even though we recognize that Vega's discovery helped awaken scholars' interest in a wide variety of music excluded from academic research, we have found the terminology to be a bit problematic when, as of late, his concept mesomúsica has at times been adopted as an equivalent to what música popular has come to mean, as we can observe in the following quote:

With his definition of popular, Vega helped situate popular music both socially and aesthetically, placing it in between classical and traditional (folklore) music, which contributed to its acceptance in academia (Gonzalez 2008). ${ }^{3}$

Such a homologation fails to comprehend, according to Vega's own terminology, that música popular, in his time, included both mesomúsica and música folklórica. A similar misunderstanding can be found in Músicas populares del Uruguay (Aharonián, 2007), written by one of the most important promoters of Vega's work.

Consequently, in view of the lack of a broadly accepted alternative concept, música popular is often used to denote popular music by default, or at least its foremost usages in academic settings. Furthermore, the various ambiguities are usually met with juxtaposing explanatory adjectives, such as urban (or urbanized) (González, 1997; González, 2008), contemporary (Adell-Pitarch, 1997; Eli Rodríguez 2005), having mass distribution and dissemination in the mass media (Woodside 2008), and finally, Western (Vilar, 2000), just to name a few, in the constant compensatory negotiation of the often different understandings of música popular that cohabitate in Latin American Popular Music Studies.

\section{A critical reading of "popular"}

Now, from a terminological standpoint, amidst the various ambiguities, there has been a growing interest regarding this dilemma. For instance, Héctor Fouce (2008) has stressed the confusion inherent in the translation of "popular culture" in the Hispanic context. Pablo Alabarces (2008), likewise, adheres to a definition that recaptures its semantic relation to "the world of the poor". Moreover, these ambiguities are not only present in the usage of the terms in question, but are inherent in their very translation. Naoki Sakai points out that:

\footnotetext{
If the foreign is unambiguously incomprehensible, unknowable, and un-familiar, it is impossible to talk about translation, because translation simply cannot be done. If, on the other hand, the foreign is comprehensible, knowable, and familiar, it is unnecessary to call for translation. Thus the status of the foreign in translation must always be ambiguous. (Sakai, 2010, p. 32.)
}

If we want to talk about the issues regarding popular music and música popular, it helps to consider examining these dilemmas via translation (as well as its subfield of terminology). Now, when we refer to translation, it is translation in the more theoretical sense, examining these processes of transfer and how they happen, even if they are generally indirect in nature.

In 1813 Friedrich Schleiermacher famously stated that there are two basic types of translation: 


\begin{abstract}
Either the translator leaves the author in peace, as much as possible, and moves the reader towards him; or he leaves the reader in peace, as much as possible, and moves the author towards him (Schleiermacher, 1977, p. 74).
\end{abstract}

This quote, which is saying, in effect, that one either translates a text favouring the semantic meaning, or the syntactic structure, has resonated until today in the field of translation studies, especially in Spanish where figures such José Ortega y Gasset, and Valentín García Yebra, have each espoused one of the two methods as the most appropriate way of communicating in translation.

Now, while one style focuses more on the form and the other on the meaning, it can be said that both poles (as well as the hybrid space in-between) undoubtedly take into account the text as a whole unit. Therefore the issue here is two-sided, and although we are presenting this, in many respects, as an issue of translation it is not totally adequate either because strictly speaking, what gets translated are texts, and not words, which may add to ambiguity of the title of a field of studies that has nevertheless still been "translated" to several other languages.

Therefore, within the framework of translation, despite the difficulties, we argue that the problem here is that the translation of popular music into música popular seemingly tends to favour translation of the form rather than the meaning. However, this is done without there really being any sort of inherent aesthetic or expressive quality of the phrase popular music that would merit what seems to be a translation that favours the visual form over the semantic usages defining both popular music and música popular in their respective sociolinguistic-institutional spaces.

In instrumental terms, we would like to introduce the concept called "false friends". False friends are not to be confused with false cognates (which are actually words that strangely sound alike and mean similar things but have no common roots). False friend are two words that look and possibly sound similar but do not mean the same thing, for example, in Spanish "pretender" means "to try", and not to pretend, whereas in English "Deception" means "Engaño" and not "decepción" which means disappointment in Spanish, etcetera. In the article "False friends: a kaleidoscope of translation difficulties", they are instead described as "deceptive cognates" due to the trouble they present to people working between two languages with common terminological roots. They also distinguish between what is a "partially deceptive cognate" and a "totally deceptive cognate" stating that partially deceptive cognates have at least one shared meaning (Granger and Swallow 1988: 108-9). This further complicates things because, as we will examine in more detail, the adjective popular does indeed have shared meaning, although they are seldom used in the same manner.

Therefore, given the strikingly different ways of understanding the concept of popular, we argue that popular music and música popular are at times, and it is important to emphasize "at times", indeed false friends, and therefore, a mistranslation.

Now the word popular itself is an adjective, stemming from the Latin term popularis in English as well as all Latin-based languages. In Raymond Williams' definition of "popular" from Keywords: a Vocabulary of Culture and Society the term is traced back to its inception into the English language as a legal term "action popular" in the fifteenth century, which, by the sixteenth century entered into more common usage, meaning both a political system carried out "by the whole people" as well as meaning lowly or base. And this is how popular remained: a top down adjective suggesting inferiority expressed by an elite ruling class about the unenlightened other.

However, as we see today, there has definitely been a shift in the connotation and usage of popular from a negative to a much more positive one. But, as Williams states, the real change was the perspective. Those at the bottom of the social order 
began to insert their own point of view in the writing of the nineteenth century. Since then, the word popular has existed both in its positive and negative form to this day.

But what is interesting is that in Spanish the definition found in the Real academia española, the authoritative body on the Spanish language, the six definitionpoints talk about popular as something pertaining to the people and marginalized classes, culturally coming from within these classes. In other words, the definition does not even touch upon heavily commercialized pop-culture, as is so often the case in English, which, in the case of popular music, while listened to and enjoyed by many marginalized social classes, is often produced and sold not by these same people, but by the cultural industry for consumption.

Now, up to this point, the most important question to ask is not whether or not popular music and música popular are false friends, it seems quite safe to say they sometimes are, but rather why and how this would take place, especially in academia, where terminology and articulation are usually scrutinized.

In order to understand this phenomenon, we propose taking Franz Van Coetsem's theory of language imposition. Jaap van Marle explains that "In Van Coetsem, borrowing is equated with the influence of a linguistically non-dominant language on a linguistically dominant language, whereas the reverse process, imposition, is defined as the influence of a linguistically dominant language on a linguistically non-dominant language." (Van Marle 2003: 123-4). Although Van Coetsem's approach to linguistic imposition is psycholinguistic in nature, we argue that it can be taken a step further into the realm of sociolinguistics, and moreover, the linguistic contact between institutions.

Just like with all language contact, when two or more institutions, in this case academic institutions, come in contact, there is almost always a disparity of power, especially considering the status of non-western, and/or global south academic institutions in Europe or North America.

For example, if a South American student chooses to go to North America to do graduate work, after having previously studied musicology in Latin America where he or she specialized in the Nueva Canción (often comparable to folk music in Anglo linguistic sphere) in the framework of Popular Music Studies, it is quite possible that the (often canonized) repertoire of what this same student is made to study to pass a comprehensive exam would be contrary - in terms of its cultural equivalent relative to the social spaces these musics occupy - to her or his pre-conceived notions and academic background in Popular Music Studies. But what happens when a student learns what popular music "really" is and then takes that back to their respective institution to teach? It seems that, undoubtedly, the linguistic "borders", to make reference once again to Sakai, are redrawn at the conceptual level in terms of new terminological uses introduced in an often unidirectional fashion, i.e., with the dominant concept transforming that with which it comes into contact.

Therefore, if Popular Music Studies are to continue to be developed across disciplinary, generational, geographic and linguistic lines, the issue of how parameters are defined, who is defining them and why, deserves a closer examination. Drawing again from Hutchinson's recent work, she quotes Michael Birenbaum Quintero from a paper he gave at the Annual Meeting of the Society for Ethnomusicology, which also resonates very much with the issue at hand applying itself easily to the terminology used in open academic spaces like those of the study of popular music:

In postcolonial societies, scholars from the Northern academy have some significant and rather regrettable advantages derived from our position, from funding possibilities to an often almost built-in legitimacy. We may end up being the sources cited further down the line to legitimise future versions of traditional music scholarship. As such, we have an important responsibility to discuss the formation 
of canons of authenticity and to inject into the discussion non-canonical forms and methods. (Birenbaum Quintero, 2006) (emphasis added).

That said, it is important to point out that interesting alternatives have indeed arisen out of these dilemmas in other marginal situations. For example, the study of popular music in the English speaking Caribbean, which shifts the paradigm to a situation in which the dominant language in question is the one also being used in a region that can sometimes be more comparable socioeconomically to its Spanishspeaking neighbours.

In an article by William R. Aho in the trilingual Latin American Music Review / Revista de Música Latinoamericana entitled "Steel band music in Trinidad and Tobago: The creation of a people's music", one can concretely see that this debate also has a lot to do with cultural geography and class, rather than just the English or Spanish language as a whole. In said article, the terms "people's music" and "popular music" both appear, seemingly interchangeable, the latter being used only at the very beginning, with people's music used to describe steel drum music as "a" popular music amongst Trinidadians that is not so commercialized in terms of the music industry. Nevertheless, much like what we have seen amongst Latin American scholars, Aho uses popular music in opposition to erudite or art musics, seemingly saying that popular music is a wide category containing both commercial and folk-type people's musics. This same term has been used to describe other marginalized socio-musical spaces (at least at the time it was written), like Sidney Finkelstein's Jazz: a People's Music published in 1948 about the predominantly black and working class jazz-scene in Harlem at the time.

Moreover, the understanding of música popular as people's music rather than popular music is also evident in Peter Manuel's previously mentioned article from Grove Music Online. Manuel categorizes the genres of modern urban popular music, rhythm and blues, Greek laika, Texas-mexican conjunto music, Indonesian dangdut and Colombian porro all under the title "people's music". In doing so, the term reconnects to its original connotation of social class, an element often disregarded in the English concept.

\section{Conclusion}

Without any intention of unifying the term música popular, our aim has been to engage the existing tensions within the field of Popular Music Studies; tensions involving terminology as well as the very definition of the object of study. As Middleton explains:

If the terms are suspect, they are not necessarily empty, they were evolved to cover something, notably certain differences in musical processes; without them we shall need new terms and distinctions, if we are not to sink into a hopelessly vague relativisation of the whole musical field $(1981$, p. 5).

The need for new terms, as Middleton rightfully states, can also translate to more complex (but not vague) understandings of already existing terms, like that of popular music, to both maintain their institutional feasibility and be more conceptually inclusive.

The adaptation of música popular's meaning in favour of the Anglophone concept popular music - or its coming to mean what was generally known as popular music - responds to, on one hand, the absence of an authoritative Spanish term to designate music disseminated on a large scale via the mass media, and, on the other, the necessity to separate the field of Popular Music Studies from the older, traditional folk music field of study. The main problem prompted by this tendency, from our point of view, is a drastic and forced separation of musical worlds that both converge and 
conflict when they come into contact and can therefore be considered popular musics, whether in English or Spanish, in their own right. However, there are also significant issues of disparity when certain terms get adopted due to the institutional prestige with which they are produced and are reproduced (both consciously and unconsciously) in other cultural settings where the terms would likely not be considered as such. In other words, building on what Birenbaum Quintero put forth, these terminological transformations have more to do with legitimacy than with local realities and seem to have stemmed mainly from the contact between institutions and academics that work together but on an unequal footing.

Nevertheless, if the fruitful study of popular music is to continue in an interdisciplinary, generational, geographic and linguistic manner, the definitions used organizationally and institutionally must be flexible enough, without being overly vague, not only to accommodate other notions of popular music (like that of Spanish speaking Latin America), but also to be critically re-examined, in so far as the study itself tests and challenges its self-determined boundaries over time.

\section{Endnotes}

1. Both 'term' and 'concept' are used somewhat interchangeably throughout this article, but it is important to note that we use 'concept' as a "mental construct seen as mediating between a word and whatever it denotes or is used to refer to" ("concept") where as we mean 'term' as "as the designation of a defined concept in a special language by a linguistic expression" (Sasu 2009) e.g. the multiple contextualized meanings that can be found in a given dictionary entry for a word or compound word.

2. [N]o pretendía dar cuenta de toda la riqueza y variedad de las músicas populares latinoamericanas, sino que enfatizar una práctica musical en particular, que había sido postergada por la musicología y la etnomusicología hasta los años ochenta. Se trata de una práctica musical urbana o urbanizada, que es definida por su masividad, mediatización y modernidad. De este modo, quisimos diferenciarnos de las prácticas musicales tradicionales, comunitarias y orales, aunque siempre manteniéndonos atentos a las intersecciones producidas entre ambos campos musicales.

3. Con su definición, Vega, ayudaba a situar social y estéticamente la música popular -ubicándola en una posición intermedia entre la música clásica y el folklore-, contribuyendo también a su reconocimiento académico (González 2008).

\section{References}

Adell Pitarch, Joan-Elies. 1997. "La música popular contemporánea y la construcción de sentido: Más allá de la sociología y la musicología". Trans-Transcultural Music Review, No. 3. article 1. consulted: 1.nov.2011.

Adorno, Theodor W. 1941. "On Popular Music." Studies in Philosophy and Social Sciences, Vol. 9: pp. 17-48.

Aharonián, Coriún. 2007. Músicas populares del Uruguay. Universidad de la República, Montevideo. 
Aho, William R. 1987. "Steel Band Music in Trinidad and Tobago: The Creation of a People's Music." Latin American Music Review / Revista de Música Latinoamericana. Vol. 8, No. 1: 26-58.

Alabarces, Pablo. 2008 "Posludio: Música popular, identidad, resistencia y tanto ruido (para tan poca furia)." Trans-Transcultural Musical Review, No. 12, article 7. consulted: 8.dec.2010.

Aravena Décart, Jorge. 2004. "Música popular y discurso académico: a propósito de la legitimación culta de las "Anticuecas" de Violeta Parra." Revista Musical Chilena. Vol. 63, No. 202: pp. 9-25. www.revistamusicalchilena.cl. consulted:1.dec.2010.

Blacking, John. 1981. "Making Artistic Popular Music: The Goal of True Folk." Popular Music, Vol. 1: pp. 9-14.

Claro Valdés, Samuel. 1979. Oyendo a Chile. Andrés Bello, Santiago.

"Concept". 2007. The Concise Oxford Dictionary of Linguistics, edited by P. H. Matthews. Oxford University Press, Oxford Reference Online. consulted: 7.jan. 2012.

Costa, Luis. 2004. "Las rumbas olvidadas: transculturalidad y etnicización en la música popular gallega". Trans - Transcultural Music Review, No. 8, article 8. consulted: 16.apr.2011.

De Surmont, Jean-Nicolas. 2008. "From Oral Tradition to Commercial Industry: The Misunderstood Path of Popular Song". International Review of the Aesthetics and Sociology of Music. Vol. 39, No. 1: pp. 73-92.

Eli Rodríguez, Victoria. 2005. "La música bailable de Cuba: del son a la timba ¿ruptura o continuidad?". Trans - Transcultural Music Review, No. 9, article 2. consulted: 16.apr.2011.

Fabbri, Franco. 2010. "What is popular music? And what isn't? An assessment, after 30 years of popular music Studies." Musiikki, No. 2: pp. 72-92.

Fabbri, Franco. 1982. "What kind of Music?" Popular Music, Vol. 2: pp. 131-143.

Finkelstein, Sidney. 1948. Jazz: a People's Music. Citadel Press, New York

Fouce, Héctor. 2008. "Emociones en lugar de soluciones. Música popular, intelectuales y cambio político en la España de la Transición." Trans- Transcultural Music Review, No.12, article 20. consulted: 8.dec.2010.

Gammond, Peter and Kenneth Gloag. 2002. "popular music". In The Oxford Companion to Music, edited by Alison Latham. Oxford Music Online. http://www.oxfordmusiconline.com/subscriber/article/opr/t114/e5287

consulted:13.nov.2010.

González, Juan Pablo. 2001. "Musicología popular en América Latina: síntesis de sus logros, problemas y desafíos." Revista Musical Chilena. Vol. 55, No. 195: pp. 38-64. www.revistamusicalchilena.cl. consulted:1.dec.2010.

González, Juan Pablo. 2008. "Los estudios de música popular y la renovación de la musicología en América Latina: ¿La gallina o el huevo?" Trans- Transcultural Music Review, No. 12, article 15. consulted: 8.dec.2010.

Granger Sylviane and Swallow, Helen. 1988. "False Friends: a Kaleidoscope of Translation Difficulties". Le Langage et l'Homme. Vol. 23, No. 2: pp. 108-120.

Hesmondhalgh, David and Neigus, Keith. 2002. Popular Music Studies. Arnold, London. 
Hutchinson, Sidney. 2011. "Típico, folklórico or popular? Musical categories, place, and identity in a transnational listening community." Popular Music. Vol. 30: pp. 245-262.

Jaujou, Nicolas. 2002. "Comment faire notre Musique du monde?" In Cahiers d'études africaines [Online], 168 | 2002, Online since 25 December 2005, http://etudesafricaines.revues.org/169; consulted 25.feb.2012. URL :

Manuel, Peter and Middleton, Richard. 2010. "Popular music." Grove Music Online. Oxford Music "Pnline. http://www.oxfordmusiconline.com/subscriber/article/grove/music/43179pg1. consulted:13.nov.2010.

Merlier, Melpo. 1960. "La chanson populaire grecque". Acta Musicologica, Vol. 32, No. 2/3: pp. 68-77.

Middleton, Richard. 1981. "Introduction." Popular Music, Vol. 1: pp. 3-7.

Moore, Allan. 2003. Analyzing Popular Music. Cambridge University Press, Cambridge.

Paddison, Max. 1982. "The Critique Criticised: Adorno and Popular Music". Popular Music, Vol. 2: pp. 201-218.

Sakai, Naoki. 2010. "Translation and the Figure of Border: Toward the Apprehension of Translation as a Social Action." Profession, No. 1: pp. 25-34.

Sasu, Laura. 2009. "Terminology Dynamics- Conceptual Patterns of Term Formation”. Bulletin of the Transilvania University of Braşov, Vol. 2, No. 51: pp. 171-174.

Schleiermacher, Friedrich. 1977. "On the Different Methods of Translating". In Translating Literature: The German Tradition from Luther to Rosenzweig, edited and translated by André Lefevere. Van Gorcum, Assen. Pp. 67-89.

Shusterman, Richard. 2003. "Entertainment: A Question of Aesthetics". The British Journal of Aesthetics, Vol. 43, No. 3: pp. 289 -307.

Storey, John. 2003. Inventing popular culture: From folklore to globalization. Blackwell Pub., Malden, MA.

Tagg, Philip. 1982. "Analysing Popular Music: Theory, Method and Practice." Popular Music, Vol. 2: pp. 37-67.

Torres Alvarado, Rodrigo. 2008. "Zamacueca a toda orquesta Música popular, espectáculo público y orden republicano en Chile (1820-1860)." Revista Musical Chilena, Vol. 63, No. 209: pp. 5-27. www.revistamusicalchilena.cl. consulted: 1.dec.2010.

Van Marle, Jaap. 2003. "Elite-Governed vis-à-vis Non-Elite-Governed Contact Situations." In When Languages Collide: Perspectives on Language Conflict, Language Competition, and Language Coexistence, ed. Brian D. Joseph. Ohio State University Press, Columbus.

Vásquez, Chalena. 2006. Message sent on December the 27th to the IASPM-AL mailinglist. Available at http://urca.unirio.br/archives/iaspm-latinoamericana.html consulted: 30.dec.2010.

Vega, Carlos. 1944. Panorama de la música argentina. Losada, Buenos Aires.

Vega, Carlos. 1966. "Mesomusic: An Essay on the Music of the Masses." Ethnomusicology, Vol. 10, No. 1: pp. 1-17. 
Vega, Carlos. 1997. "Mesomúsica: un ensayo sobre la música de todos." Revista Musical Chilena, Vol. 51, No. 188: pp. 75-96. www.revistamusicalchilena.cl consulted: 1.dec.2010.

Vilar. Josep M. 2000. "Colin Cripps: La música popular en el siglo XX". Trans Transcultural Music Review, No. 5, article 12. consulted:16.apr.2011.

Williams, Raymond. 1976. Keywords: A Vocabulary of Culture and Society. Fontana, London.

Wiora, Walter. 1966. The Four Ages of Music. Dent, London.

Woodside, Julian. 2008. "La historicidad del paisaje sonoro y la música popular". Trans - Transcultural Music Review, No. 12, article. consulted: 16.apr.2011. 